\title{
Academic Uses of Google \\ Earth and Google Maps in a
}

Library Setting

\begin{abstract}
Over the last several years, Google Earth and Google Maps have been adopted by many academic institutions as academic research and mapping tools. The authors were interested in discovering how popular the Google mapping products are in the academic library setting. A survey was conducted to establish the mapping products' popularity, and type of use in an academic library setting. Results show that over 90 percent of the respondents use Google Earth and Google Maps either to help answer research questions, to create and access finding aids, for instructional purposes or for promotion and marketing. The authors recommend expanding the mapping products' user base to include all reference and liaison librarians.
\end{abstract}

\section{INTRODUCTION}

Since their launch in 2005, Google Maps and Google Earth have had an enormous impact on the way people think, learn, and work with geographic information. With easy access to spatial and cultural information, Google Maps/Earth has provided users with the means to understand their world and their communities of interest. Moreover, the customizable map features and dynamic presentation tools found in Google Maps and Google Earth make each one an attractive option for someone wanting to teach geographic information or make customized maps. For academic researchers, Google Mapping applications are also appealing for their powerful ability to share and host projects, create customized KML (Keyhole Markup Language) files, and to easily communicate their own research findings in a geographic context.

Recognizing their potential for revitalizing map collections and geographic education, the authors felt that many academic libraries were also going to be active in using Google Maps/Earth for a variety of purposes, from promoting their services to developing their own Google KML files for users. With Google Earth's ease of use and visualization capabilities, it was even thought that academic libraries would be using Google Earth heavily in instruction classes bringing geographic information to subject areas traditionally outside of geography.

As active users of Google Maps/Earth in their roles as academic librarians at their universities, the authors became curious to know what other academic librarians were doing with Google Maps/Earth, particularly those working with maps and/or geography subjects. Were they using

Eva Dodsworth (edodsworth@uwaterloo.ca) is Geospatial Data Services Librarian, University of Waterloo Library, Waterloo, and Andrew Nicholson (andrew.nicholson@utoronto.ca) is GIS/Data Librarian, Hazel McCallion Academic Learning Centre, University of Toronto Mississauga, Ontario 
the technology as part of their librarian roles on campus? How were they using it? What impacts was it having in how they delivered library services?

To help answer these questions, the authors set out on a three-stage process with the aim of providing a more complete picture of Google Maps/Earth use in academic libraries. The first stage consisted of a literature search focusing on library and information science research databases, to see what (if any) scholarly research had been written that discussed the role of Google Maps/Earth in academic libraries. The second stage of the research had the authors examining over a dozen academic library websites to assess how they were integrating Google Maps/Earth either through an API plug-in on their website or advertising other Google Maps/Earth related services and collections. The third stage had the authors compile a set of twenty survey questions which were then distributed to academic librarians across Canada and the United States, probing the use of Google mapping products in the academic library setting.

\section{LITERATURE REVIEW}

Despite the ubiquity of Google for information searching, there was a surprising paucity of literature that documents the impact of Google Maps/Earth in academic libraries. Nevertheless, there are some articles which indicate just how much Google Maps can help raise the profile of library services.

Terry Ballard, a librarian at Quinnipiac University, describes in a few articles how he and colleagues were able to use Google Earth placemarks to promote his library's special collections. ${ }^{1}$ The potential for "Discovering the Library with Google Earth" is also a theme in an article by Brenner and Klein in which the Portland State University Library linked their urban planning documents collection to Google Earth for ease of searching. ${ }^{2}$

Although the focus is on public libraries, Michael Vandenburg documents how his library system began "using Google Maps as an interface for the library catalogue." In his article, Vandenburg discusses that the inspiration for such a project came about through various Google Maps mashups that were popular on search oriented websites such as "Housing Maps," which combined realtor listings from Craigslist with a Google Maps API. Using API coding, Vandenburg was able to link latitude and longitude data of countries to individual OPAC records enabling a visual search for items at the country level. ${ }^{3}$

While these articles focused on use of Google Earth as a collection discovery tool, Troy Swanson notes the visualization aspects of the applications and their utility for teaching information literacy. Swanson has students use Google Earth and Second Life as tools to create a virtual exhibit on Malcolm X. Although Swanson notes that the final output by the students did not meet the initial expectations, valuable learning opportunities for teaching in a 3D space were recognized and should be pursued. ${ }^{4}$ Some of these opportunities are highlighted as case studies by Lamb, noting the visualization aspects of Google Earth would be very useful for librarians providing instruction. ${ }^{5}$ 


\section{Google Maps/Earth \& Academic Libraries: A Scan of Selected Library Websites}

For the next stage, the authors performed an environmental scan of academic Library websites to see how they are using and implementing Google mapping technology into their services. Many are doing creative and innovative project work which will, we hope, encourage and guide other libraries to consider doing something similar. Mapping technology can be used in several different ways, and with Internet users becoming more proficient using this technology, libraries have the opportunity to take advantage of this communication medium. Any document or image that has a geographic component can be digitized and made easily accessible using online mapping technology.

The following section will review some of the projects highlighted on websites. The projects can be grouped into the following categories: finding aids, collection distribution, and teaching and reference services.

\section{$\underline{\text { Finding Aids }}$}

All collections in libraries require some sort of finding aid to locate library material-the most obvious one being the library catalog. However, there are many location-based materials that use customized finding aids such as map and air photo indexes, and geospatial data coverage maps. For several years now libraries have been trying to make access to the finding aids easier by digitizing them and offering them online. Not only are online versions easily updatable, but they are quite often created using Google technology, allowing for the use of modern basemaps and zoom capabilities. Traditional paper indexes can be difficult to navigate, especially the historical ones, making the search process rather difficult for users and library staff.

One of the most popular types of online indexes created by libraries is air photo indexes. Most map libraries collect air photos, and many use similar indexes to help locate aerial photography for an area of interest. Several libraries have digitized the indexes making the same information available online. Users simply zoom into a geographical area and click on a point to retrieve the photo information they need in order to locate the air photo in the library collection. Some libraries will even send an electronic copy of the photo to the users. The McGill University Library, for example, has made its air photo information available from their webpage in a KML format to be viewed in Google Earth. Users can click on a point of interest to easily obtain the air photo information. McGill Library has also digitized topographic indexes, making them also available via Google Earth. ${ }^{6}$ The University of Western Ontario's Serge A. Sauer's Library also provides its air photo indexes online, incorporating Google Maps directly into their website. Placemarks representing individual photos have been inserted on a Google Map, along with the photo description so that when users click on the placemark, photo information is released.

Using Google mapping technology to offer online finding aids that are searchable by location is an innovative and cost-free step towards collection accessibility. What would make these types of library collections even more accessible, however, is offering users online access to digital versions of the collection items themselves. So to bring the indexing project one step forward, not only would the photo reference information be made available, but the actual image would be too, 
thereby allowing libraries to use Google mapping technology as an avenue for collection distribution and delivery.

\section{Collection Delivery}

Libraries have had digital collections for quite some time. Many of course do not need to digitize resources themselves as they subscribe to products such as electronic journals and books. However there are still some less common collections that are physically housed in libraries that would be much more accessible to users if they were exposed and made available online. An Internet search has shed light on numerous digitization projects that use Google mapping technology to search for and deliver location-based collections. Examples of these types of collections include historical maps and air photos, archived photos and postcards, audio interviews, community information, textual documents like letters and diaries, and GIS data.

McMaster University Library is one example of a library that has digitized a historical map collection and made it available online. An index to its World War I military maps and aerial photography was created using Google Maps, and was embedded into its webpage. ${ }^{7}$ Users can click on an area of interest to bring up the corresponding high resolution map image. Likewise, Brock University Library has also offered its historical air photo collection online, allowing users to search using a Google Map, and then download photos of interest. ${ }^{8}$ Additionally, Yale University Library has created KML indexes of its fire insurance plans, with direct links to the digitized images. ${ }^{9}$ The University of Connecticut Library has digitized its local historical maps and using Google Maps had created a map mashup which includes historic landmarks. Clicking on the landmarks provides users with links to related resources.

Several libraries have digitized other imagery, such as postcards and photography. This is particularly popular with archival and specialized collections. The University of Vermont Library has embedded a Google Map into its website with placemarks that when clicked lead the user to the library's Long Trail Collection, an assortment of over 900 images of the oldest long-distance hiking trail in the United States. The images have been digitized from hand-colored lantern slides. ${ }^{10}$ Cleveland State University Library has also done something similar with its Cleveland Memory Project, in which Google Maps were embedded into the library webpage and placemarks of local historic landmarks added. When users click on the placemarks, they are able to access a description of the landmark along with a photograph of it. Clicking on "more information" will lead the user to several related resources, including the library catalog, where original documents about the location are available (e.g., images, books). ${ }^{11}$

Besides digitizing their collections, some libraries have also georeferenced them so that they could not only be accurately located using an index, but so that they could be viewed in Google Earth (KML format). Offering collections in KML format greatly increases exposure and use of geographic resources because Google Earth is one of the more popular location-based applications used by library users and the public. Geographic files such as georeferenced air photos and satellite images, as well as GIS data used to be only viewed in specialized GIS programs. But GIS technology has evolved into so many online applications, offering all computer users the benefits of geographic information and a platform to distribute information. 
The University of Waterloo Map Library is one example of a library that had digitized its historical air photo collection and made the images available in KML format for Google Earth usage. ${ }^{12}$ Users can access a map index of the available photos from the Map Library webpage and then click on the index to download the images.

The University of North Carolina Library has georeferenced several historical maps and made them available for viewing as an image overlay in Google Maps. This particular mapping project consists of around 150 thematic maps, including historical soil surveys, road and highway maps, city/county maps, and more. Users can take advantage of the georeferenced maps and accurately compare historical features to modern ones with Google Maps' basemap. Having a preview of the dataset before it is downloaded assists the user in downloading only what is needed. ${ }^{13}$

Perhaps more popular than a library's air photo collection are libraries' collections of geospatial data. Geospatial, or GIS data, has traditionally been only used by users who have access to GIS programs such as Esri's ArcGIS, or ArcView. More recently, librarians have discovered that when spatial files are converted into easy-to use file formats, such as KML, the user group is broadened and the files are used more. So it is no surprise that several libraries have converted their GIS shapefiles (a spatial data file format used specifically in GIS programs) into KML files and made them available for download from their webpages. University of Connecticut Library offers its GIS files online in various formats, including KML. It also provides a sample image of the GIS layer in Google Maps. ${ }^{14}$ Baruch College at the City University of New York has made neighborhood census data available in Google Maps. The geographic boundary files were overlaid in Google Maps, and clicking on the map will lead users to the files available from the American Census Bureau's Fact Finder.

Clearly, many libraries have incorporated Google Mapping Technology into their digitization projects. The technology has proven capable of attracting collections that are not strictly locationfocused such as maps and air photos, but that have a location associated with it, such as archival photos of community landmarks or books written about a specific locale. Google mapping technology makes the organization and storage of collections relatively effortless for library project managers, and it makes collection searching and distribution simple and friendly for the users.

\section{Other Uses of Google Maps/Earth in Libraries}

Perhaps one of the simplest uses of Google mapping technology can be illustrated by visiting several library websites. Many libraries have embedded Google Maps into their website as either a webpage header ${ }^{15}$

\section{Survey: What are Academic Library Staff doing with Google Maps/Earth? ${ }^{16}$}

Following the review of the literature and academic library websites, the authors wanted to discover how academic librarians themselves were using Google Maps and Google Earth in their work, if at all. To capture this data, the authors compiled a set of survey questions targeting those in the academic library community who work with maps, GIS, or geography/geology/earth science subject matter. 
In preparing the survey questions, the authors were aware of a "survey fatigue" among the academic library community. At the time of research, many surveys were going out to librarians requesting their time and responses, so the authors wanted to keep the survey concise both in terms of number of questions, but also in the types of questions. In the end, the survey was created with twenty questions consisting of six yes/no questions, seven multiple choice, and the remaining seven questions being short answer. For distributing the survey, the authors wanted to reach as many librarians who worked with maps, geospatial data and government document subject matter as possible. The survey was then distributed on specialized map library and government publication listservs, including Maps-L, GovInfo, GIS4LIB, and CARTA (Canadian Maps \& Air Photo Systems forum). The survey was also distributed on the members' only lists belonging to the Association of Canadian Map Libraries \& Archives (ACMLA) and the Western Association of Map Libraries (WAML) listservs. The survey was made available on Survey Monkey for two months from December 2010 to the end of January 2011.

\section{The Responses}

With the survey available during a quieter period of library activities, and thanks to a couple of reminder emails being sent out on the lists, our questionnaire received a total of 83 responses.

\section{Who is using Google Maps/Earth?}

The first couple questions dealt with the department or area of the library in which the respondent worked in, and what their position encompassed. As expected, a large majority of respondents, 81 percent, worked in "Map/GIS Services" while 28.8 percent also had "General Reference" responsibilities. Other Library Service areas mentioned included "Data Services" and "IT," as well as some that fell outside library boundaries where staff worked in Geography and Environment Science Departments.

Not surprisingly, 52 percent of the responses indicated that their position was "librarian," with the majority being "GIS librarian" or "map librarian." Others included "reference \& instructional services librarian" and "science librarian." Also received were 17 responses from GIS specialists, library technicians and map assistants. What was especially noteworthy was that 12 responses were from library administrators, directors, or department heads who were finding time to work with Google Earth as part of their responsibilities. This number also included GIS coordinators and map curators responsible for making decisions in their departments.

\section{Google Mapping Products : What is being used, how often and for what purpose?}

To gain an understanding of how library staff are using Google mapping products, a series of questions was asked of the respondents to determine which products were being used, how often and for which tasks. Respondents were given a list of all the Google mapping products available, and were asked to indicate which ones they had worked with.

Not surprisingly, the top two products used by respondents were Google Maps, 93 percent (71) and Google Earth, 91 percent (69). Google Maps API had been used by 40 percent (30) of the respondents, followed by Google Earth Pro at 38 percent (29). Eight percent (6) had also worked with Google Earth API, and 7 percent (5) had used Google Earth Plus. Interestingly, one respondent indicated that they had deployed Google Earth Enterprise in their Library. 


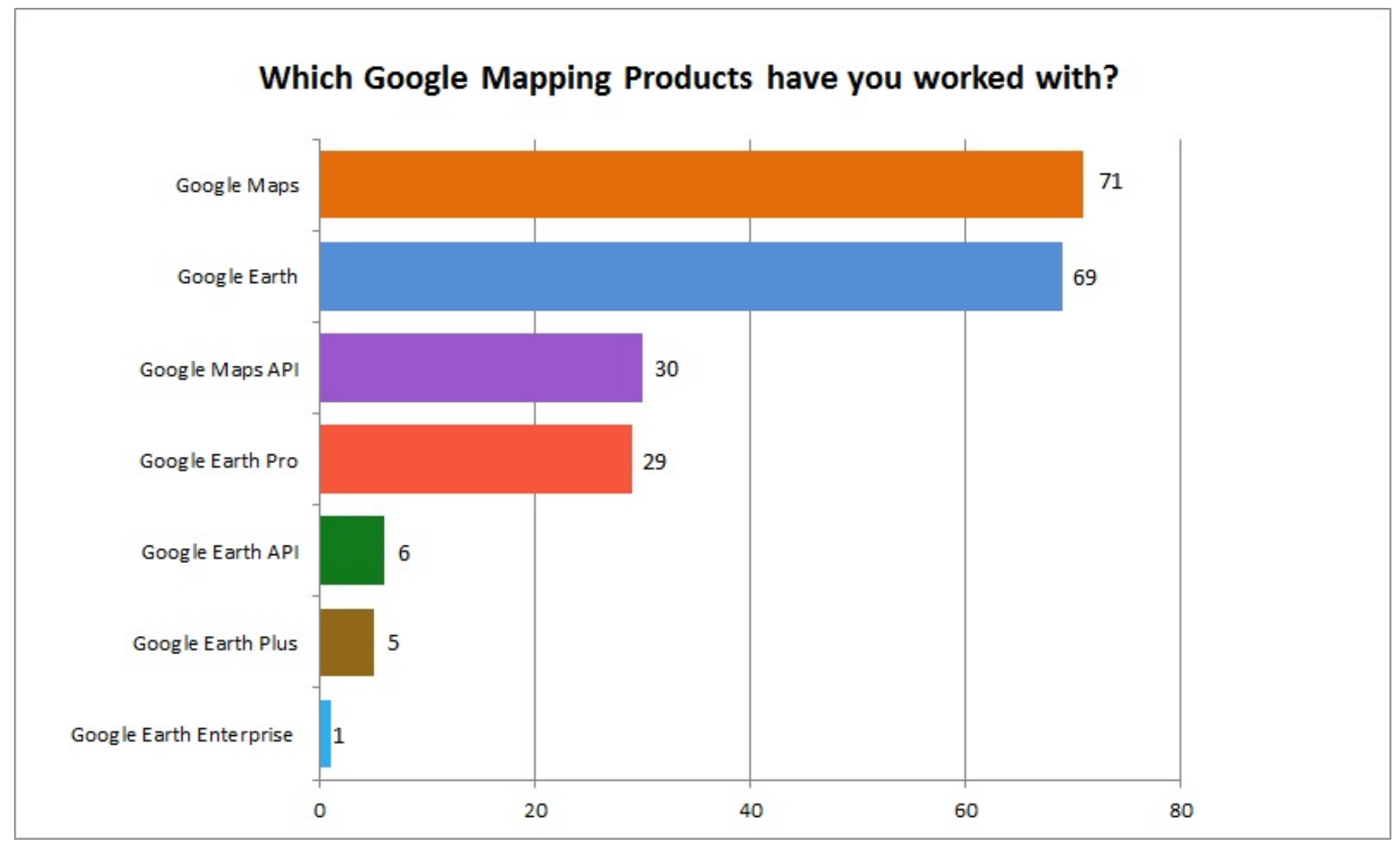

Figure 1. Respondents' Use of Google Mapping Products

Since many of these users may have simply used the products occasionally, it was important to get a sense of how often the products were being used. When asked the question "How regularly do you work with Google mapping products for work-related projects?" 69 percent (54) responded that they use the products at least once a month. Of those responses, 45 percent (35) use them at least weekly. Specifically, eighteen percent (14) use them one to two times a week, thirteen percent (10) use them three to four times a week, and fourteen percent (11) use them even more often than that. Only six percent (5) responded that they don't use the products at all. 


\section{How regularly do you work with GoogleMapping Products for work-related projects?}

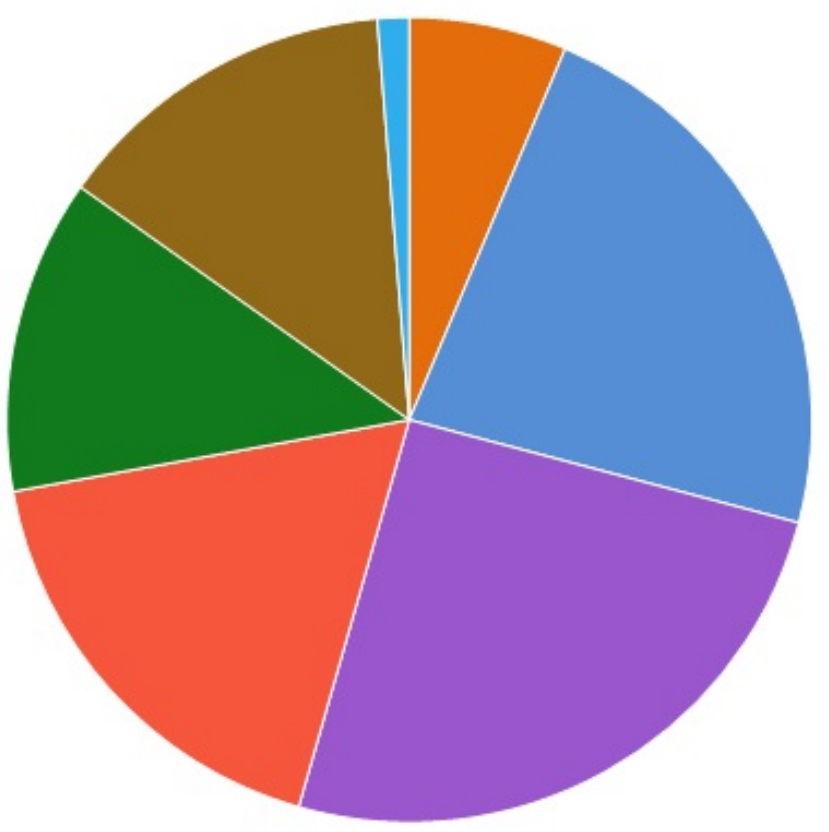

Not at all

A few times a year

1-3 times a month

1-2 times a week

3-4 times a week

More often than that!

Not sure

Figure 2. Frequency of Use for Work-Related Projects

As Google Maps/Earth can be used in many different ways and for different purposes in a library environment, the survey inquired how in fact these products were being used in their libraries. The survey question listed four possible tasks that the technology could be used for with the additional option for respondents to enter their own 'other' usages. Respondents could check off all that applied.

The options given included:

- Instruction

- Promotion/Marketing

- Answering Research Questions

- Creating/Accessing a Finding Aid Tool (Air Photo Map Indexes, etc.)

- Other: (Fill in answer)

The majority of respondents, 82 percent (58) indicated they were using the products to answer research questions; 61 percent (43) for creating or accessing a finding aid tool; 56 percent (40) for instruction purposes; 27 percent for promotion/marketing and 20 percent (14) have used them for "other" purposes including georeferencing imagery, for use in webpages or creating learning objects. 


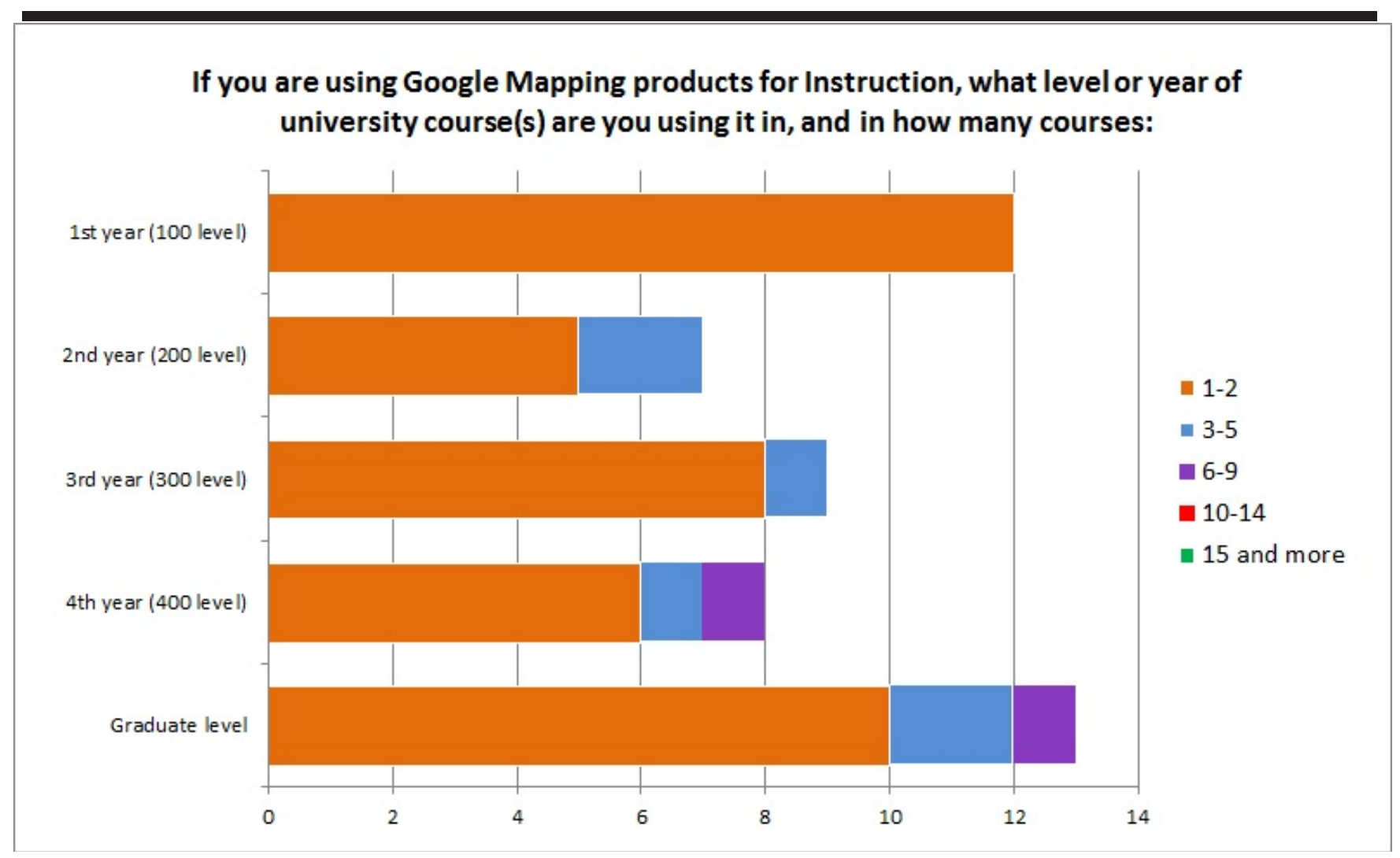

Figure 3. Level and Frequency of Use in Instruction

Are Google Mapping Products being used for Library Instruction?

For the authors, one of the best aspects of Google Maps/Earth applications is their visualization capabilities. The ability to easily create and display geographic information to engage students makes Google mapping applications an ideal instruction tool. In many ways, Google Maps and Google Earth have helped promote map and spatial literacy as concepts that are teachable.

Despite the free availability and ease of use of Google Mapping applications, the authors were somewhat surprised from the survey to find that 72 percent of Library staff surveyed noted that their institution did not have any kind of map, spatial, or geospatial literacy policy in place.

When it came time to provide instruction in the classroom, the survey found that only 31 percent (26) of the respondents had even used Google Earth in a classroom. Nevertheless, in looking at the course levels, library instruction with Google Earth tools is actually occurring at all levels, from first year to graduate. Significantly however, the frequency of the instruction seems to peak in the fourth year, where staff are using in upwards of six to nine courses. Respondents were asked to give some details of these sessions, and they included a variety of class topics from Environmental awareness education for first year students, to learning digitization skills in later years.

Has your Library taken advantage of Google Map/Earth Technology for promotion or marketing purposes? 
From our environmental scan of Library websites we saw many interesting uses of Google Maps and Google Earth that were embedded directly into websites. Perhaps because of this the authors were surprised to find that 55 percent of the survey respondents did not believe their library was using these technologies for promotion or marketing purposes.

For those respondents who were using Google Maps or Google Earth to boost services for users, quite a few provided interesting examples of what this technology can offer. Many were using Google Map APIs to enhance map and aerial photo indexes, creating greater awareness of these resources and enhancing access. One respondent noted they had created a campus tour that highlighted all of the buildings that made up the library system, while others were using Google API technology to showcase particular digitization projects such as folklore collections or geologic atlases.

When asked if such activities have helped to enhance services or provided benefits to users, many responded that they had for both the users and for other library staff. Greater speed and an increased familiarity of the collections were cited by several respondents, who no longer need to consult the paper indexes.

Does the Library provide support to the wider campus community using Google Mapping products (not including instructional collaborations)?

Although many libraries are now using Google Maps and Google Earth technology, the authors were surprised that many were not actively leveraging this expertise across their campuses. Almost all the respondents either skipped the question or stated that they were not providing this kind of active support. Several noted that their GIS services were open to all and that they were responsible for the Google Earth Pro licences on campus, but that this was the extent of their support.

\section{Working with Google Map/Earth (KML) Files}

In the last few years, KML files have become one of the more popular ways to display and distribute geographic information online. With its ease of use, and access, KML files have considerably broadened the user base of geographic information. KML files can be easily created in Google Earth, and they can be easily converted from GIS files in specialized programs. It is this ease of access and usability that has popularized geographic information, hence increasing exposure to library collections and services. This survey was therefore interested in determining how libraries are using and creating KML files.

When survey respondents were asked whether they work with KML files, 64 percent (47) responded they did, with 85 percent (40) claiming that they create their own KML files. For those who create their own, 92 percent (34) said that they created KML files by converting them from another file format using an external application, such as ArcGIS, Earthpoint, OGR20GR, or Shp2KML software. 78 percent (29) also created them in Google Earth, and 32 percent (12) created KML files by writing their own XML code.

The authors were most interested to know if KML files were actually held as part of the Library Holdings. Thirty percent (13) of respondents noted that they provide access to their KML files as 
part of their collections, with 89 percent, (8) claiming they could be located through the library website. Other areas mentioned for access included LibGuides and specialized GIS data catalogues available through the Library's website.

In terms of quantity, one respondent claimed a collection of 500-800 KML files, while other responses mentioned amounts in the ranges from 5 to 100, with some claiming that they were not sure exactly how many made up their collection.

What other Online Mapping Tools are used in your Library apart from Google Maps and Google Earth?

Although Google Maps and Google Earth are perhaps the most well-known online mapping tools available, the authors were also interested to learn if there were other products that libraries were using as part of their service offerings. As expected many mentioned Esri's ArcGIS online and Esri's ArcExplorer, while other responses included Bing Maps, OpenStreetMap, and Open Layers.

\section{DISCUSSION}

Google mapping applications are clearly being used for academic purposes in library settings. With such diverse capabilities made available in these programs, library professionals are using them in several different ways. Google Earth and Google Maps are popular among library staff who work with GIS and/or map collections. In fact, over 90 percent of the respondents use both products, either to help answer research questions, to create and access finding aids, for instructional purposes or for promotion and marketing. Google Mapping products have also helped libraries revitalize their collections as well as assist in transferring spatial information literacy skills to academic students and faculty. The authors hope that readers who work in a Map/GIS library setting will be inspired by the many examples of online mapping projects outlined in this paper and they will too use the online tools to the benefit of their library and their library users. Google mapping products offer libraries an online platform to share information, and resources in an easy, accessible and low-cost way.

The survey results also indicate that map/GIS professionals in academic libraries trust and rely on Google Maps/Earth as a solution to many academic queries and needs. Since Google mapping products were created for the use by mainstream society, it can be suggested that all other nonmap and GIS related fields may find the products to be beneficial and useful to them as well. Google Earth and Google Maps are very easy to learn and the users do not require any spatial or mapping skills. As this survey was limited to map/GIS users, the authors do not know how, if at all, Google mapping products are being used by other library staff. This will be a future area of study. The authors do strongly suggest however for map/GIS librarians to consider offering training sessions to reference staff and liaison librarians. As a multidisciplinary tool, many subject areas can benefit from Google Maps/Earth, as it's certainly not a tool for use by only GIS/map librarians. With a little bit of training, all library staff can use Google mapping products to assist with research questions, spatial literacy, location-based projects and library instruction. In fact, library staff members responsible for nontraditional library material such as photographs, postcards, audio recordings, original hand-written documents, etc. may want to consider using online mapping products to organize their collection. Too many times such original material is lost in the library's filing system, is irretrievable or unavailable during convenient hours. Google Maps/Earth will organize all collections based on their geographic location and can offer access to the actual 
material. More exposure to and training on these free and easy to use products can increase collection use, promote mapping technology, and organize the library's holdings.

\section{REFERENCES}

1 Terry Ballard, “Inheriting the Earth: Using KML Files to add placemarks relating to the library's original content to Google Earth and Google Maps" New Library World 110 (2009): 357-65, doi: 10.1108/0307480091097579. Jacobsen, Mikael and Terry Ballard, “Google Maps: you are here: using Google Maps to bring out your library's local collections” Library Journal, October 15, 2008 (accessed September 11, 2011). http://www.libraryjournal.com/article/CA6602836.html.

2 Michaela Brenner and Peter Klein, "Discovering the Library with Google Earth" Information Technology and Libraries 27 (2008): 32-6.

3 Michael Vandenburg, "Using Google Maps as an interface for the Library Catalogue" Library HiTech 26 (2008): 33-40.

4 Troy Swanson, “Google Maps and Second Life: Virtual Platforms meet Information Literacy” College \& Research Libraries News 69 (2008): 610-12.

${ }^{5}$ Annette Lamb, and Larry Johnson, "Virtual Expeditions: Google Earth, GIS, and Geovisualization Technologies in Teaching and Learning" Teacher Librarian 37 (2010): 81-5.

${ }^{6}$ A list of McGill Library's air photo indexes can be viewed at http://www.mcgill.ca/library/library-findinfo/maps/airphotos/ (accessed September 8, 2011).

7 McMaster University Library Map Index can be found at http://library.mcmaster.ca/maps/ww1/ndx5to40.htm, (accessed September 8, 2011).

8 The Brock University Historical Air Photo Collection can be accessed at: http://www.brocku.ca/maplibrary/airphoto/historical.php (accessed September 8, 2011).

9 The Yale University Sanborn Indexes can be found at http://www.library.yale.edu/MapColl/print sanborn.html (accessed September 8, 2011).

10 The University of Vermont Library's Google Map can be found at: http://cdi.uvm.edu/collections/browseCollection.xql?pid=longtrail\&title=Long\%20Trail\%20P hotographs (accessed September 8, 2011).

11 The Cleveland Memory Project can be found at: http://www.clevelandmemory.org/hlneo/ (accessed September 8, 2011). 
12 The University of Waterloo Map Library website can be found at: http://www.lib.uwaterloo.ca/locations/umd/project/ (accessed September 8, 2011).

13 The University of North Carolina Library provides interactive maps at http://www.lib.unc.edu/dc/ncmaps/interactive/overlay.html (accessed September 8, 2011).

14 The University of Connecticut Library offers GIS files online here: http://magic.lib.uconn.edu/connecticut data.html (accessed September 8, 2011).

${ }^{15}$ Campus Map examples include: Yale University Library at http://maps.commons.yale.edu/venice/ example maps for Library locations on campus include: Brock University Library, http://www.brocku.ca/maplibrary/general/where-is-the-ML.php University of North Carolina, http://www.lib.unc.edu/libraries collections.html (All accessed on September 8, 2011).

16 The full survey instrument can be found in the appendix of this document. 


\section{APPENDIX}

\section{Google Maps and Google Earth: Influences and Impacts in your Library}

\section{You and Your Library}

1. What is your work position title?

2. What department/division/area of library do you work in? (Click all that apply)
o Map/GIS Services
o Government Publications
o General Reference
o Technical Services
o Other (please specify):

\section{Google Mapping Products}

3. Please check all the products you have worked with?
o Google Maps
o Google Maps API
o Google Earth
o Google Earth Plus
o Google Earth Pro
o Google Earth API
o Google Earth Enterprise

4. How regularly do you work with Google Mapping Products for work-related projects?
0 Not at all
o A few times a year
o 1-3 times a month
o 1-2 times a week
o 3-4 times a week
o More often than that!
o Not sure

5. For what work related tasks, have you used these products? (Click all that apply)

o Instruction

o Promotion/Marketing

o Answering Research Questions

o Creating/Accessing a Finding Aid Tool (Air Photo, Map Indexes, etc.) 


\section{Library Instruction using Google Mapping Products}

6. Does your Library have a Map, or Spatial, or Geospatial Literacy Policy or Program?
o Yes
o No

7. If you are using Google Mapping products for Instruction, what level or year of university course(s) are you using it in, and in how many courses:

\begin{tabular}{|l|l|l|l|l|l|}
\hline & $1-2$ & $3-5$ & $6-9$ & $10-14$ & $\begin{array}{l}\text { 15 and } \\
\text { more }\end{array}$ \\
\hline $\begin{array}{l}1^{\text {st }} \text { year (100 } \\
\text { level) }\end{array}$ & & & & & \\
\hline $\begin{array}{l}2^{\text {nd }} \text { year (200 } \\
\text { level) }\end{array}$ & & & & & \\
\hline $\begin{array}{l}3^{\text {rd }} \text { year (300 } \\
\text { level) }\end{array}$ & & & & & \\
\hline $\begin{array}{l}4^{\text {th }} \text { year (400 } \\
\text { level) }\end{array}$ & & & & & \\
\hline Graduate level & & & & & \\
\hline
\end{tabular}

8. Please describe some of these activities?

9. Does your library offer geographic awareness or GIS-related training to some or all the library staff?

\section{Promotion/Marketing using Google Mapping Products}

10. Has your library used Google Mapping Technology to promote, offer, or deliver a service? (For example, offering KML files for download, indexes, guides, scanned documents, placemarks/URLs from Google Maps/Earth, etc.)

$$
\begin{array}{ll}
\text { o } & \text { Yes } \\
\text { o } & \text { No }
\end{array}
$$

10a. If yes, please describe with as much detail as possible how your library has used Google Mapping technology. If possible, please provide links to the projects.

10b. If yes, how have the Google Mapping related projects enhanced services or benefited the library? 
11. Does the Library provide support to the wider campus community using Google Mapping products (not including instructional collaborations)?

\section{$\underline{\text { KML/KMZ collections }}$}

12. Do you work with KML files?
o Yes
o No

13. Do you create your own KML files?
o Yes
o No

14. How do you create your own KML files?
O Write XML code
o Save in Google Earth
o Convert from another file format using an external application
O Other (please specify)

15. Does your library hold and provide access to KML or KMZ files as part of its collections?
o Yes
o No

16. If yes, approximately how many files do you currently hold?

17. How are these files findable by your patrons?
o OPAC
o Library Website
o Both

18. Do you or other library staff use other online mapping tools? Please list which ones and what they are used for. 